\title{
The Consumer Behavior Among Muslim Millennials in Buying Sharia Stock in the City of Kudus
}

\author{
Bayu Tri Cahya ${ }^{1 *}$, Farah Nadifa ${ }^{2,}$ Muslim Marpaung ${ }^{3,}$ Luqmanul Hakiem Ajuna $^{4}$
}

\author{
1,2 State Islamic University of Kudus \\ ${ }^{3}$ State Polytechnic of Medan \\ ${ }^{4}$ Sultan Amai State Islamic University of Gorontalo \\ ${ }^{*}$ Corresponding author. Email: cahyab380@gmail.com.
}

\begin{abstract}
The urgency of public education from saving society to investing society is needed at this time to increase interest in investing. This research is to determine whether consumer behavior (halal knowledge, Islamic religiosity, financial technology, and risk) on the Buying of Sharia Stock. The design of this study is quantitative. The population and sample involved in the research are the millennial generation of Muslims in the city of Kudus. Sampling in this study using purposive sampling technique. This study uses a questionnaire survey method to collect data, and uses multiple linear regression to analyze the data. The results of this study show that halal knowledge and financial technology variables have a significant positive impact on the purchase of Shariah stocks.
\end{abstract}

Keywords: Stock, halal knowledge, Islamic religiosity, financial technology, and risk

\section{INTRODUCTION}

Investment is the first step in production activities and becomes a factor for increasing economic growth. Therefore, investment is essentially an initial step for economic development activities. The dynamics of investment affect the level of economic growth, reflecting the high and low levels of development (Mutiari, 2016). The opinion on the importance of investment in supporting the development of developing countries began with the discovery of a growth model after World War II, namely in the 1950s and 1960s.

Usually, people invest because they want high returns or meet their expectations. In addition to returns, investors also have the concept of risk. Investment risk can be defined as the possibility of a difference between actual returns and expected returns. The two concepts of risk and return are like the two sides of a coin, they are always placed side by side. That is to say, when investing, in addition to calculating the expected return, investors must also be shrewdly looking for investment options that can provide the highest expected return under a certain risk level, or investment options that can provide a certain return under the lowest risk level (Tandelilin,2001).

PT Kustodian Sentral Efek Indonesia (KSEI) noted that the number of investors in the capital market until December 27, 2019 reached 2.4 million single investor identification (SID). This number increase $53.04 \%$ from the period at the end of December 2018 for 1.6 million SID 'www.ksei.co.id. Despite this drastic increase, the number of Indonesian investors is still less than neighboring countries namely Malaysia and Singapore. It is clear that the Indonesian people have a short term financial orientation or in the category of saving society (saving). When compared with developed countries the orientation is more to the long term or in the category of investing society (investment).

To increase interest in investing in the Indonesia Stock Exchange (IDX), the Clearing and Guarantee Institution (CGI) and PT KSEI as facilitators of the Indonesian capital market are trying to increase the number of Indonesian investors in various ways, for example by advertising and creating a concept of strong capital market industry and on a national scale with the aim of increasing awareness of the Indonesian capital market (Ari Wibowo, 2019). Socialization and education on campus have been carried out, either directly or indirectly. Direct socialization and education in the campus environment, including: seminars, workshops, training, simulations and competitions both at regional and national levels, even up to the international level. Meanwhile, indirect socialization and education, namely by utilizing media both electronic media, print media and online media. 
IDX's collaboration with universities with the presence of investment galleries is also an appropriate means of stock education for students. The existence of this investment gallery aims to provide facilities for students to be able to access all information about the Islamic capital market. Even students can also access direct practice through trading simulations. Support from securities companies was also carried out, especially in providing easy access for students to open accounts and start trading, with only Rp. 100,000.00 can already make transactions (Ferry Khusnul Mubarok, 2018). Investment Gallery is a financial literacy program aimed at student groups. This program has been launched since 2000. The establishment of an investment gallery, which is a development from a corner of the stock exchange, is a means of introducing the world of the capital market from an early age to the academic community on campus, especially to students. This investment gallery has a 3 in 1 cooperation concept between the IDX, universities, and securities companies. The significant difference between the stock exchange corner and the investment gallery is the main objective of the stock exchange corner is only to educate the capital market to elements on campus, while the investment gallery not only performs an educational function, but also stimulates the growth of new investors from among students and listed issuers. new originating from a business or business managed by the student. This is done as a way to overcome the problem of the low number of local investors in Indonesia, which is only around 400 thousand of the total population of Indonesia. This figure is the lowest compared to countries in Southeast Asia, such as Malaysia, Singapore, Thailand and the Philippines (Hasrini Sari, 2018).

The investment gallery is at the forefront of increasing the number of investors in Indonesia because the results of the OJK study show that the number of investors is increasing along with higher education. In addition, investment galleries play a very important role in encouraging an increase in the number of investors, especially students from universities outside Java. Currently, the number of investors is still centered on the island of Java at $77.15 \%$ www.ksei.co.id.

The most popular financial market instruments in the capital market are stocks. stocks are a sign of the participation or ownership of a person or entity in a company or limited person (Darmadji, 2015). Issuing stocks is one of the company's options when deciding to fund the company (Nurlita, 2014). The development of Islamic stocks which is considered quite significant has made investors start to look at sharia-based stocks, not just investors who do require sharia conditions in investing. So that the sharia-based economy is considered to be the most appropriate for now, including investing in sharia-based stocks (Febrianti, 2018).

The Kustodian Sentral Efek Indonesia (KSEI) noted that the 20-30 year old millennial generation dominates retail investors in the Indonesian capital market. The percentage of young investors at the end of 2019 reached $43.28 \%$ of the total capital market investors, which amounted to 2.4 million investors. Www.ksei.co.id. This data shows that millennials are starting to look to investing in the capital market. These events are certainly influenced by various factors.

Based on several previous studies related to factors that influence interest in investing in Islamic stocks, including research conducted by Ari Wibowo in 2019, it shows that investment knowledge and minimal capital affect investment interest (Ari Wibowo, 2019). In addition, Syaeful Bakhri's research in 2018 shows that there is no relationship between investment income and investment interest of IAIN Syekh Nurjati Cirebon students. The analysis results show that there is no relationship between IAIN Syekh Nurjati Cirebon students' appreciation and investment interest. (Syaeful Bakhri, 2018 The economic condition variables of students with investment interest in IAIN Syekh Nurjati Cirebon students also have no relationship. Furthermore, Ahmad Dahlan Malik's research in 2017, this study analyzed the factors that influence investor interest through the UISI investment gallery exchange in the form of risk factors, levels income, motivation, knowledge, perception, and learning in investing in the Islamic capital market (Ahmad Dahlan Malik, 2017). The significant independent variables are risk, income and motivation variables which are important to pay attention to respondents or investors in BGIU (UISI Investment Gallery Exchange) compared to others because these variables have a positive regression.

The results of previous studies are still contradictory to one another, so further research is needed to determine which research results can be supported. Researchers are trying to examine the investment interest of the millennial generation that research on this matter in the city of Kudus has not been done much and the addition of a new Islamic Investment Gallery in the city which is nicknamed the city of kretek is the Sharia Investment Gallery at the State Islamic Institute of Kudus so it is necessary and interesting to do. This study seeks to reveal the factors that influence the Buying of Sharia Stock in the city of Kudus in terms of aspects of Halal Knowledge, Islamic Religiosity, Fintech, and Risk. Of the four factors, it is consumer behavior or consumer behavior. Consumer behavior is actions taken by individuals, groups, or organizations that are related to the decision-making process to obtain, use, economic goods or services that can be influenced by the environment.

\section{LITERATURE REVIEW}

\subsection{Theory of Planned Behaviour}

Theory of planned behavior has a foundation on a belief perspective that encourages implementing specific behaviors (Azjen, 1991). The perspective of trust is carried out by combining various characteristics, qualities and attributes of certain information which then forms the will to behave (Ni Nyoman Anggar Seni, 2017). 
Theory of planned behavior states that if you want to predict a person's intentions, knowing that belief is as important as knowing one's attitude (Ni Nyoman Anggar Seni, 2017). Behavior control will then influence intention. Behavioral control refers to a person's perception of their ability to behave. The stronger the behavior, subjective norms and the greater the control of a person's behavior, the stronger their intention to behave in certain conditions.

This theory explains that humans tend to act according to their intentions and perceptions of control through certain behaviors, where the dimensions of intention are influenced by behavior, subjective norms and behavioral control. The assessment and consideration of potential investors arises because of the awareness to act. The attitude and views of an investor towards stock trading can become stronger when he makes a decision to achieve a certain level of financial stability, where recommendations from people around him, the environment and his genes (male and female) will shape the behavior patterns for these investors. When the intention to invest has been obtained, investors will generally start to consider. A person who has a positive attitude towards stock investing, gets support from those around him, there are no obstacles to investing in stocks, then someone's intention to invest in stocks will be even higher.

\subsection{Markowitz Portfolio Theory}

Markowitz said that "don't put all your eggs in one basket", because if the basket falls, all the eggs in the basket will break (H. J. Markowitz, 1959). The concept of this theory is known as investment diversification or investing that is not focused on one area only, but is more in one area and is also not carried out in one direction.

Investment comes from the English language, namely Investment. The word invest as the root word for investment that means plant. In capital and financial market terms, the word investment is defined as investment of money or capital in a company or project with the aim of obtaining profit. Meanwhile, Ismanthono defines investment as the act of investing money in the form of cash, assets, and other securities in the hope that it will get benefits in the future as income from the investment (Henricus W. Ismanthono, 2006).

\subsection{Consumer Behaviour}

David L. Loudon and Albert J. Della Bitta, argued that "consumer behavior may be defined as decision process and physical activity individuals angage in when evaluating, acquiring, using or disposing of goods and service." (David L. Loudon and Albert J. Della Bitta, 1984).

Consumer behavior can also be interpreted as actions taken by individuals, groups, or organizations related to the decision-making process to obtain, use, goods or economic services that can be influenced by the environment (Etta Mamang Sangadji, 2013). Consumer behavior to make a purchase is influenced by the environment including cultural factors, social class factors, personal influence factors, family factors, and situation factors (Danang Sunyoto, 2013). In this study the researchers included elements of cultural factors, social class factors, personal influence factors, family factors, and situation factors from factors of halal knowledge, Islamic religion, financial technology and risk.

\subsubsection{Halal Knowledge}

Knowledge is defined as the professional knowledge and skills acquired by a person or group of people through theoretical or practical understanding of a specific subject (Adiba, 2018). Good knowledge about halal products is influenced by information and experience about halal products. Consumers who know more about halal products will have greater potential for actual behavior, such as direct purchase of halal products. The increase in investment in Islamic stocks is driven by knowledge, information about halal products, and more and more religious consumers. Ultimately, these consumers will gain more knowledge and information about halal products, which can influence their interest in investing in Shariah stocks.

\subsubsection{Islamic Religiosity}

Religion is a problem related to human inner life (Jalaluddin, 2015). Religion is a form of belief. Religion can also be interpreted as teaching that was handed down by God for guidance for people in living their lives (Bustanuddin Agus, 2006). The meaning of the word relegare is to bind together in common unity (Faisal Ismail, 1997). From this religious term, what is called religiosity emerges. Religiosity as a religious commitment (which is related to religion or faith beliefs), which can be seen through the activities or behavior of individuals related to the religion or belief in their faith (Fuad Nashori, 2002). For a Muslim, religiosity can be seen from the extent of knowledge, belief, implementation and appreciation of the religion of Islam. From the above definition, religiosity in Islam involves five things, namely aqidah, worship, charity, morals (ihsan) and knowledge (Jalaluddin, 2015).

\subsubsection{Financial Technology}

Financial Technology or abbreviated as fintech, is translated in Indonesian as financial technology. In simple terms, fintech can be interpreted as the use of information technology developments to improve services in the financial industry (OJK, 2017). Financial technology products and services are very affordable and efficient, especially for consumers who live in locations or areas that do not have a modern economic structure. Financial Technology can not only make these financial products and services affordable, financial technology 
can also lower costs associated with these two things (Irma Muzdalifa, 2018).

\subsubsection{Risk}

Risk is defined as the possibility of an actual return that is different from the expected return (Eduardus Tandelilin, 2001).. In economics in general and investment science in particular there is an assumption that investors are rational beings. In general, the description of the relationship between risk and return is as follows:

Figure 1. Relationship Between Expected Return and Risk

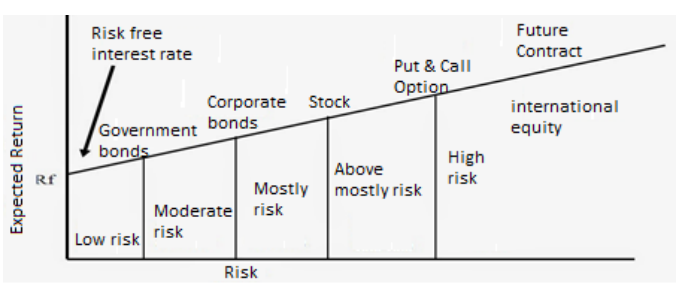

\subsection{Hypothesis}

As for the problems that the authors put forward and in order to direct this assessment, the authors propose the following hypothesis:

\subsubsection{The influence of Halal Knowledge on the}

\section{Buying of Sharia Stock}

In previous studies, there were studies that used independent variables of knowledge, such as Dini Rusqiati's research in 2016 which stated that knowledge had a positive effect on investment interest in the Islamic capital market. A similar research was also conducted by Siti Latifah 2019 which stated that knowledge has a positive effect on interest in investing in Islamic stocks. Based on the descriptions and results of previous studies, the following hypothesis can be formulated:

$\mathrm{H} 1$ = Halal Knowledge has a significant effect on the Buying of Sharia Stock

\subsubsection{The Influence of Islamic Religiosity on The}

\section{Buying of Sharia Stock}

Research conducted by Dini Ruqsiati states that Islamic Religiosity or religion has a significant relationship in the distribution of income, shares and has a significant effect on consumption behavior. Investors who are more religious, will increasingly make real purchases (actual) of halal products. Based on the descriptions and results of previous studies, the following hypothesis can be formulated:
$\mathrm{H} 2$ = Islamic Religiosity has a significant effect on the Buying of Sharia Stock

\subsubsection{The influence of Fintech on the Buying of}

\section{Sharia Stock}

President Director of KSEI Friderica Widyasari welcomes the increasing number of millennial investors in the capital market. According to her, this increase was driven by developments in capital market technology which made it easier for investors to invest. One of the technologies that has developed and is able to stimulate the desire of young people to invest is the presence of financial technology, especially making it easier for them to invest in reksadana.

Research conducted by Bayu Tri Cahya and Nila Ayu Kusuma in 2019 stated that there was a positive and significant influence between technological advances and interest in stock investment. With the development of technology, it makes access to the capital market easier, so that it creates high interest in investing. Based on the descriptions and results of previous studies, the following hypothesis can be formulated:

H3 = Fintech has a significant effect on the Buying of Sharia Stock.

\subsubsection{The effect of risk on the buying of the}

\section{Buying of Sharia Stock}

The convenience of investing in securities is the ease with which you can form an investment portfolio, that is, you can diversify your investment (selecting more than one investment) on various investment opportunities. The minimum action taken to take advantage of the excess funds is to save or make deposits. This minimal action is carried out by a person who is classified as risk averse. Unlike the case with people who are classified as risk takers, they tend to invest their funds in forms of investment that provide greater returns even though the risks faced are also large, such as investing in stocks (Tendelin, 2001).

Research conducted by Ahmad Dahlan Malik stated that there was a significant positive relationship between risk and public interest in investing in the Islamic capital market through the UISI investment gallery. This is because in addition to providing a sizable return, Islamic stocks also have a big risk. Based on the descriptions and results of previous studies, the following hypothesis can be formulated:

H4 = Risk has a significant effect on the Buying of Sharia Stock. 


\subsection{Conceptual Framework}

Schematically, based on the theoretical basis and previous research that has been stated above, the hypothesis raised by the research design to describe the flow of problems and expected answers and the testing model can be described as follows:

\begin{tabular}{l|l|}
$\begin{array}{l}\text { 1. Halal Knowledge } \\
\text { 2. Islamic Religiosity } \\
\text { 3. Fintech } \\
\text { 4. Risk }\end{array} \mid \rightarrow \quad \begin{array}{c}\text { The Buying of } \\
\text { Sharia Stock }\end{array}$ \\
\hline
\end{tabular}

\section{RESEARCH METHOD}

\subsection{Data Collection and Sample Selection}

This research is a type of field research with a quantitative approach design. The data collection technique used is a questionnaire method. The population in this study is the Muslim millennial generation in the city of Kudus. For the sampling, this research uses purposive sampling technique, that is the generation who have participated in the training at least once and have traded at least 1 time at the Islamic Investment Gallery of the State Islamic Institute and the Investment Gallery of the Indonesia Stock Exchange, Muria Kudus University.

\subsection{Identification and Measurement of Operational Variables}

Table 1. Operational Variables

\begin{tabular}{|l|l|l|}
\hline Variable & \multicolumn{1}{|c|}{ Definition } & Indicator \\
\hline $\begin{array}{l}\text { The Buying } \\
\text { of Sharia }\end{array}$ & $\begin{array}{l}\text { The tendency of a person to } \\
\text { Suy or take actions related to } \\
\text { the buying of Islamic stocks } \\
\text { (Assael, 1998) }\end{array}$ & Motivation \\
& $\begin{array}{l}\text { Tral } \\
\text { Knowledge }\end{array}$ & $\begin{array}{l}\text { Knowledge is defined as the } \\
\text { professional knowledge and } \\
\text { skills acquired by a person } \\
\text { or group of people through } \\
\text { theoretical or practical } \\
\text { understanding of a specific } \\
\text { subject. Therefore, it can be } \\
\text { said that halal knowledge is } \\
\text { knowledge about halal } \\
\text { products. (Elfira Maya and } \\
\text { Dewi Ayu, 2018) }\end{array}$ \\
\hline $\begin{array}{l}\text { Islamic } \\
\text { Religiosity }\end{array}$ & $\begin{array}{l}\text { Religiosity as a religious } \\
\text { commitment (which is } \\
\text { related to religion or faith } \\
\text { beliefs), which can be seen } \\
\text { through the activities or }\end{array}$ & \\
\hline
\end{tabular}

\begin{tabular}{|c|c|c|}
\hline & $\begin{array}{l}\text { behavior of individuals who } \\
\text { are related to the religion or } \\
\text { faith belief. For a Muslim, } \\
\text { religiosity can be known } \\
\text { from the extent of } \\
\text { knowledge, belief, } \\
\text { experience, appreciation, and } \\
\text { consequences for Islam. } \\
\text { (Fuad Nashori and Rachmy } \\
\text { Diana Muchram, 2002) }\end{array}$ & $\begin{array}{l}\text { Experience } \\
\text { Appreciation } \\
\text { Knowledge } \\
\text { Consequences }\end{array}$ \\
\hline Fintech & $\begin{array}{l}\text { Financial Technology or } \\
\text { abbreviated as Fintech is the } \\
\text { result of a combination of } \\
\text { technology and financial } \\
\text { services, which changes the } \\
\text { business model from } \\
\text { conventional to moderate. } \\
\text { (Ernama Santi, 2016) }\end{array}$ & $\begin{array}{l}\text { Convenience } \\
\text { Efficent } \\
\text { Flexible }\end{array}$ \\
\hline Risk & $\begin{array}{l}\text { Risk can be interpreted as a } \\
\text { form of uncertainty about a } \\
\text { situation that will occur later } \\
\text { with decisions made based on } \\
\text { various considerations at this } \\
\text { time (Irham Fahmi, 2017) }\end{array}$ & Uncertainty \\
\hline
\end{tabular}

\section{RESULTS AND DISCUSSION}

\subsection{Instrument Test Results}

Based on the results of the validity test conducted by the researcher, most of the items used as instruments in the questionnaire showed valid results. Meanwhile, the reliability test results show the results of data processing, the Cronbach Alpha value is bigger than 0.70. So, it is concluded that the variables of the Buying of Sharia Stock, halal knowledge, Islamic religiosity, financial technology, and risk can be said to be reliable.

\subsection{Classical Assumption Test Results}

Table 2. Classic assumption test

\begin{tabular}{|c|c|c|}
\hline Assumption & Test Result & \\
\hline $\begin{array}{l}\text { Normality test } \\
\text { Kolmogorov-Smirnov Z } \\
\text { Asymp. Sig. (2-tailed) }\end{array}$ & $\begin{array}{l}0,416 \\
0,995\end{array}$ & \\
\hline $\begin{array}{l}\text { Heteroscedasticity Test } \\
\text { Sig }\end{array}$ & $\begin{array}{l}\text { Halal Knowledge } \\
\text { Islamic Religiosity } \\
\text { Financial Tech. } \\
\text { Risk }\end{array}$ & $\begin{array}{l}0,809 \\
0,244 \\
0,220 \\
0,930\end{array}$ \\
\hline $\begin{array}{l}\text { Multicolinearity Test } \\
\text { Tolerance }\end{array}$ & $\begin{array}{l}\text { Halal Knowledge } \\
\text { Islamic Religiosity } \\
\text { Financial Tech. }\end{array}$ & $\begin{array}{l}0,570 \\
0,802 \\
0,620\end{array}$ \\
\hline
\end{tabular}




\begin{tabular}{llc}
\hline & Risk & 0,917 \\
& & \\
& Halal Knowledge & 1,756 \\
VIF & Islamic Religiosity & 1,246 \\
& Financial Tech. & 1,614 \\
& Risk & 1,090 \\
& & \\
\hline
\end{tabular}

Based on the table above, the normality test results show the Kolmogorov-Smirnov $\mathrm{Z}$ value of 0.416 with a $\mathrm{p}$ value (Sig) of 0.995 which is above 0.05 . This means that the research data is normally distributed. The Heteroscedasticity test shows that none of the independent variables statistically significant affect the dependent absolute value of Ut (Absut). So it can be concluded that there is no heteroscedasticity in the regression model. While the multicolinearity test, it is known that there is no VIF value for each variable that is greater than 10 and each variable in this study has a tolerance value of more than 0.1 . So, there is no multicolinearity between independent variables in the regression model.

\subsection{Multiple Regression Test Result}

Table 3. Hypothesis Testing Results

\begin{tabular}{|c|c|c|}
\hline Hypothesis Test & \multicolumn{2}{|l|}{ Test Result } \\
\hline $\begin{array}{l}\text { Determination } \\
\text { Coefficient Test } \\
\left(\text { Adjusted } \mathrm{R}^{2} \text { ) }\right.\end{array}$ & 0,256 & \\
\hline $\begin{array}{l}\text { Simultaneous } \\
\text { Significance Test FF } \\
\text { Sig }\end{array}$ & $\begin{array}{l}9,496 \\
0,000\end{array}$ & \\
\hline $\begin{array}{l}\text { Partial Significance } \\
\text { Test } \\
\text { (T Test) } \\
\text { Standard } \\
\text { coefficient }\end{array}$ & $\begin{array}{l}\text { Halal Knowledge } \\
\text { Islamic Religiosity } \\
\text { Financial Tech. } \\
\text { Risk }\end{array}$ & $\begin{array}{l}0,127 \\
0,111 \\
0,079 \\
0,135\end{array}$ \\
\hline $\mathrm{T}$ & $\begin{array}{l}\text { Halal Knowledge } \\
\text { Islamic Religiosity } \\
\text { Financial Tech. } \\
\text { Risk }\end{array}$ & $\begin{array}{l}2,474 \\
0,934 \\
2,138 \\
0,722\end{array}$ \\
\hline Sig & $\begin{array}{l}\text { Halal Knowledge } \\
\text { Islamic Religiosity } \\
\text { Financial Tec } \\
0,035 \\
\text { Risk }\end{array}$ & $\begin{array}{r}0,015 \\
0,353 \\
\text { chnology } \\
0,472 \\
\end{array}$ \\
\hline
\end{tabular}

\section{DISCUSSION}

\subsection{Effect of Halal Knowledge on the Buying of Sharia Stock}

Based on the variable, halal knowledge is a variable that has a positive and significant effect on the buying of sharia stock the city of Kudus. This is supported by the results of the $t$ test which results in the $t$ value of the halal knowledge variable of 2.474 , so it is bigger than the $\mathrm{t}$ table (1.984) and the level of significance (Sig) of 0.015 which is below 0.05 .

This shows that many millennials in the city of Kudus know about Islamic stock products or understand the halalness of a stock. Consumers who are more knowledgeable will have an effect on their behavior when evaluating the attributes of a halal product, will have more potential for actual behavior such as buying halal products directly.

This research is in line with the theory of planned behavior which states that attitude towards behavior is an important point in being able to predict an action. A positive attitude, support from the surrounding environment, and the perception of convenience because there are no obstacles to behavior, a person's intention to behave in making decisions is higher ( $\mathrm{Ni}$ Nyoman Anggar Seni, 2017). The view or attitude and intention to invest will not work well without knowledge of Islamic stock products.

\subsection{The Effect of Islamic Religiosity on the Buying of Sharia Stock}

Based on the results of data processing, the variable Islamic religiosity is a variable that does not significantly influence the buying of Islamic stocks in the city of Kudus. This shows that the millennial generation in the city of Kudus is not committed to their religion because the attitudes and behaviors that are reflected do not make religion the foundation in terms of making decisions. The millennial generation in Kudus can be said to have been able to distinguish between good and bad and what can be done and what cannot be done according to the commands and prohibitions of Allah SWT. However, each individual has a different personality. There are individuals who understand these rules and implement them, there are also individuals who understand these rules but do not implement them.

\subsection{Effect of Financial Technology on the Buying Sharia Stock}

Based on the results of data processing, the variable Financial Technology is a variable that has a positive and significant effect on the buying of sharia stock in the city of Kudus. The results of this study are in line with the statement of the president director of KSEI, Friderica Widyasari, according to her that the increase in Islamic stock investment is driven by the development of capital market technology which increasingly influences investors to invest. One of the technologies that is 
developing and able to stimulate the desire of young people to invest is the presence of financial technology.

In this study, respondents are aware of the importance of investing in the capital market and feel supported by the technology used because investment becomes easier to do. This shows that the millennial generation in the city of Kudus is currently literate with technology and feels the benefits so that the financial technology variable has a significant effect on the variable of buying Islamic stocks and shifts the view about the use of technology towards investment which is considered to have a more complicated process. This research is in line with the theory of planned behavior which states that the attitude or viewpoint and intention to invest will not work well without facilities that support investment activities.

\subsection{Effect of Risk to the Buying of Sharia Stock}

The risk variable is a variable that does not significantly influence the buying of sharia stock in the city of Kudus. This is supported by the results of the t test which results in the $t$ value of the risk variable of 0.722 , so it is lower than the table (1.984) and the significance level (Sig) of 0.472 which is above 0.05 .

The results of this study are not in line with the research conducted by Ahmad Dahlan Malik which states that there is a significant positive relationship between risk and public interest in investing in the Islamic capital market through the UISI investment gallery exchange (Malik, 2017). .

This shows that the millennial generation in the city of Kudus has dared to take big risks. So that risk is not a major consideration factor in investing in Islamic stocks. Most of them already know the risks that can occur when investing in Islamic stocks, have a high courageous attitude and have the view that investing in stocks will get large returns, are supporting factors to continue investing in Islamic shares.

This research is not in line with the theory of planned behavior which states that attitude towards behavior is an important subject that is able to predict an action (Seni, 2017).

\section{CONCLUSIONS}

Based on the results of the data analysis that has been carried out and the discussion described above, it can be concluded that the variables of halal knowledge and financial technology are variables that have a positive and significant effect on the the Buying of Sharia Stock in the city of Kudus. Meanwhile, Islamic religiosity and risk variables are variables that do not significantly influence the buying of sharia stock in the city of Kudus.

The limitation in this study is that the scope is still limited to the millennial generation in the city of Kudus, so to get general conclusions, a broader research is needed by expanding the object of research. In addition, further researchers are expected to be able to examine the factors that influence the buying of sharia stock by selecting or adding other independent variables and not forgetting to add research subjects with different backgrounds to get more comprehensive results.

\section{REFERENCES}

[1] E.A. Adiba and D.A. Wulandari. "Pengaruh Halal Knowledge, Islamic Religiosity, dan Attitude terhadap Behavior Konsumen Muslim Generasi Y Pengguna Kosmetik Halal di Surabaya." INOBIS: Journal of Indonesian Business and Management Innovation 1, no.3. 2018, pp. 357- 369. DOI: 10.31842/jurnal-inobis.v1i3.42

[2] B. Agus. Agama dalam kehidupan Manusia: Pengantar Antropologi Agama. Jakarta: Raja Grapindo Persada. 2006.

[3] H. Assael. Consumer Behavior and Marketing Action.Shouth-Weatern College Publishing: Cincinnati. 1998

[4] I. Azjen. The Theory of Planned Behavior. Organizational Behavior And Human Decision Processes. 1991.

[5] S. Bakhri. Minat Mahasiswa dalam investasi di Pasar Modal. Al- Amwal 10, no.1. 2018. Pp. 146-157 DOI : $\underline{10.24235 / \text { amwal.v10i1.2846 }}$

[6] B.T. Cahya, and N. A. Kusuma. "Pengaruh Motivasi dan Kemajaun Teknologi terhadap Minat Investasi Saham," Journal of Economics and Islam 7, No.2. 2019 $\mathrm{pp}$. 192-207. DOI: https://doi.org/10.24952/masharif.v7i2.2182

[7] Darmadji, Tjiptono and Hendy M. Fakhruddin..Pasar Modal di Indonesia. Jakarta: Salemba Emban Patria. 2015

[8] I. Fahmi. PengantarPasar Modal. Bandung: IKAPI. 2017.

[9] I. Fahmi. Pengantar Teori Portofolio dan Analisis Investasi. Bandung: Alfabeta. 2018.

[10] S. Febrianti. "Analis Perbandingan Kinerja Indeks Saham Syariah dengan Indeks Saham Konvensional Periode 2015 - 2017 (Studi Kasus pada JII LQ45)." Prosiding SENDI_U.2018. pp. 546-551. https://www.unisbank.ac.id/ojs/index.php/sendi_u/a rticle/view/6033/1899

[11] I. Ghozali. Aplikasi Analis Multivariate denga Program IBM SPSS 19. Semarang: Publisher Universitas Diponogoro. 2011.

[12] F. Ismail. Paradigma Kebudayaan Islam: Studi Kritis dan Refleksi Historis. Jogyakarta: Titian Ilahi Press. 1997

[13] Jalaludin. Psikologi Agama. Jakarta : PT. Raja Grafindo Persada. 2012

[14] Ototritas Jasa Keuangan.Perlindungan Konsumen Sektor Jasa Keuangan: Perlindungan Konsumen 
pada Fintech. Jakarta: Department of Consumer Protection OJK. 2017.

[15] David L. and Albert J. Della Bitta. Consumer Behavior Concept and Aplication, Second Edition .New York: Mc. Graw Hill Book Co. 1984.

[16] A.D. Malik. Analisa Faktor - Faktor yang Mempengaruhi Minat Masyarakat Berinvestasi di Pasar Modal Syariah melalui Bursa Galeri Investasi UISI," Journal of Islamic Economics and Business 3, no.1. 2017. pp. 61-84 http://dx.doi.org/10.20473/jebis.v3i1.4693

[17] H. Markowitz. Portofolio Selection: Efficient Diversification of Investment . New York: John Wiley. 1959

[18] F. K. Mubarok. Peran sosialisasi dan edukasi dalam menumbuhkan minat investasi di pasar modal syariah. Inovasi Journal Feb.UNMUL 14, no.2. 2018. $\mathrm{pp}$ $113-122$ DOI: http://dx.doi.org/10.29264/jinv.v14i2.4119

[19] I. Muzdalifa, I.A. Rahma, and B.G. Amalia. Peran Fintech dalam Meningkatkan Keuangan Inklusif pada UMKM di Indonesia", Jurnal Masharif alSyariah: Jurnal Ekonomi dan Perbankan Syariah 3, no. 1.2018 . pp 1-24 DOI: http://dx.doi.org/10.30651/jms.v3i1.1618

[20] F. Nashori and R D Muchram. Mengembangkan Kreativitas dalam Perspektif Psikologi Islam. Jogyakarta: Menara Kudus. 2002

[21] A. Nurlita. Investasi di Pasar Modal Syariah Dalam Kajian Islam.” Jurnal Penelitian sosial keagamaan 17, no.1. 2014. pp. 1-20. http://ejournal.uinsuska.ac.id/index.php/Kutubkhanah/article/view/80 6

[22] D. Rusqiati. Faktor - Faktor yang Mempengaruhi Peminat Saham untuk Memilih Saham Syariah di Kota Banjar Masin. Jurnal SPREAD 6, no.2. 2016. pp. 9-16. http://journal.stiei-kayutangibjm.ac.id/index.php/jibk/article/view/238/156

[23] E. M. Sangadji and Sopiah. Perilaku Konsumen. Yogyakarta: ANDI OFFSET. 2013.

[24] E. Santi. Pengawasan Otoritas Jasa Keuangan terhadap Financial Technology (Peraturan OJK 77/pojk.01/2016. Diponogoro Law Journal 6, no.3. 2017. pp. $1-20$. https://ejournal3.undip.ac.id/index.php/dlr/article/vi ew/19683/18645

[25] H. Sari and M. R. A Pradana. Perancangan Strategi Pemasaran Galeri Investasi Berdasarkan Faktorfaktor yang Mempengaruhi Intensi Investor untuk Berinvestasi. Jurnal Ilmiah Teknik Industri 17, No.2. $2018 . \quad$ Pp. 158-168 DOI: https://doi.org/10.23917/jiti.v17i2.5887

[26] M. Sari, M.N. Syechalad, and S.A. Majid. Pengaruh Investasi Tenaga Kerja dan Pengeluaran Pemerintah terhadap Pertumbuhan Ekonomi di Indonesia. Economic Journal And Public Policy 3, No.2. 2016. pp.

109-115. http://jurnal.unsyiah.ac.id/EKaPI/article/view/5606/ $\underline{4638}$
[27] N.N.A. Seni and N.M.D. Ratnadi. Theory of Planned Behavior untuk memprediksi Niat Berinvestasi," E-Journal Economi and Business 6, No. 12. 2017. pp. 4043-4068 DOI: https://doi.org/10.24843/EEB.2017.v06.i12.p 01

[28] E. Tandelilin. Analisis Investasi dan Manajemen Portofolio. Yogyakarta: BPFE. 2001.

[29] K. Umam and H. Sutanto. Manajemen Investasi. Bandung Pustaka Setia. 2017.

[30] A. Wibowo and Purwohandoko. Pengaruh Pengetahuan Investasi Kebijakan Modal Minimal Investasi dan Pelatihan Pasar Modal terhadap Minat Investasi (Studi Kasus Mahasiswa FE Unesa Yang Terdaftar Di Galeri Investasi FE Unesa). Journal of Management Science 7 Department of Management, Faculty of Economics Universitas Negeri Surabaya, no. 1.2019 pp. 192-200. https://jurnalmahasiswa.unesa.ac.id/index.php/jim/a rticle/view/25386/23267. 